\title{
Performance study and economic analysis of photo-voltaic thermal system under real- life thermal loads in tropical climate
}

\author{
Sivanand Somasundaram * (iD) and Andrew A. O. Tay
}

\begin{abstract}
The paper describes the implementation of a photo-voltaic thermal (PVT) system for a student hostel located in Singapore to cater for hot water requirements of the hostel and a part of electricity requirement. Real-time data monitoring was carried out by extensive instrumentation and data logging. Two different types of PVT collectors (glazed and unglazed) were used. Experimental results of performance of the individual collector arrays (thermal and photo-voltaic efficiency) along with the system overall efficiency are reported for a one-year period. Finally, an economic analysis of a typical PVT system for tropical climates is carried out and results are presented in the form of internal rate of return, net present value and payback period. PVT appears as a favourable technology in space starved areas like urban cities.
\end{abstract}

Keywords: PVT, Solar thermal, Test bedding, Tropical weather

\section{Introduction}

With ever increasing prices of non-renewable energy resources and also due to greenhouse emissions, there has been more interest in the use of cleaner and cheaper sources of energy particularly solar energy. So far, the main focus has been to tap the energy in the form of electricity using photovoltaic (PV) cells or to use the conventional thermal collectors to produce hot water. In relatively recent times, however, there have been several attempts to integrate electricity and heat generation in a single collector called PVT (photo-voltaic thermal). These collectors are built by attaching a thermal absorber below the PV panel. This serves twofold purposes of cooling the PV panel (thereby increasing the electrical efficiency) and collecting the un-utilized thermal energy to provide hot water. An added advantage of a PVT collector is that it can maximize the usage of available roof space.

Besheer et al. [1] described a comprehensive review of different structural variations in PVT collectors (both air and water) that have been reported so far to enhance thermal energy extraction. This serves as a good point to

\footnotetext{
* Correspondence: sivanand.sm@gmail.com

Department of Mechanical Engineering, National University of Singapore, Singapore 117575, Singapore
}

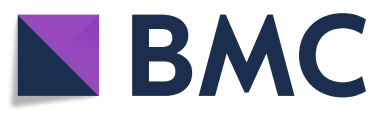

(c) The Author(s). 2019 Open Access This article is distributed under the terms of the Creative Commons Attribution 4.0 International License (http://creativecommons.org/licenses/by/4.0/), which permits unrestricted use, distribution, and reproduction in any medium, provided you give appropriate credit to the original author(s) and the source, provide a link to the Creative Commons license, and indicate if changes were made. The Creative Commons Public Domain Dedication waiver (http://creativecommons.org/publicdomain/zero/1.0/) applies to the data made available in this article, unless otherwise stated. ferent PVT systems and summarized different cooling media used and system configurations. They also compared active and passive systems. A brief summary of existing analytical models was also given. Others [3, 4] gave a brief overview of the different solar flat plate PVT technologies, their efficiencies, applications, advantages, limitations and research opportunities available.

Farshchimonfared et al. [5] described the optimization and sensitivity analysis of a PVT (air) system linked to residential building for space heating. It described the importance of geometrical optimization in the overall system efficiency. Guo et al. [6] described PVT systems linked with desiccant cooling systems and reviewed the role of channel diameter, mass flow rate and glazed covers for production of high-temperature water $\left(50-60{ }^{\circ} \mathrm{C}\right)$ from PVT systems.

Dubey and Tiwari [7] and Good [8] described the environmental impact of PVT systems and conclude that they have much shorter payback periods in terms of both energy payback and greenhouse gas emissions. Shihabudheen and Arun [9] described the performance of a PVT system measured over a period of two months and extended to a year using Monte Carlo simulations. 
Dubey and Tay [10] described the design and modeling of a $10 \mathrm{kWp}$ system along with hot water production for 100 students in a hostel. The previous work included only design and simulation; however, in the current work the PVT panels were actually installed in the student hostel as described below and subsequently a year-long real-time data measurement were done.

In summary, the PV thermal technology has been researched widely and mostly studied at the module level. There are very few systematic studies of large-scale commercial installation of PVT systems with full data measurement over a complete year. Moreover, there are very few detailed studies on economic analysis of PVT systems based on real-time data and also very little data regarding cost break-up distribution in the total cost involved in setting up a large-scale PVT system. Consequently, the current study tries to fill this gap and to provide feedback and suggestions for future PVT commercial installations. The key questions which the current work addresses are: a) What is the economic feasibility of installing a PVT system in tropical climate like Singapore? b) What are the advantages and disadvantages of glazed and unglazed type PVT collectors? and c) How significant is the thermal load profile on the performance of PVT system?

\section{Methods}

\section{Design and implementation}

In the present work, we report the performance and financial feasibility of a PVT system installed in a student hostel in Singapore. The average solar radiation in Singapore over the year is typically around $435 \mathrm{~W} \mathrm{~cm}^{-2}$. The system was installed in one block of a student hostel on campus of the National University of Singapore. The hostel block had about 97 student residents occupying four floor levels, with each level having 5 shower cubicles. The electricity supply to the water heaters was controlled by a control system to supply electricity only when the solar tank temperature went below a set value (typically $40^{\circ} \mathrm{C}$ ). Tempering valves were installed before shower inlet lines to prevent the supply of overheated solar hot water. The electricity produced by the PVT panels was converted by an inverter (with an inbuilt maximum power point tracker), metered and fed to the hostel grid, partially fulfilling the electricity needs. The circulation water pump was also automatically controlled depending on tank temperature and module temperature. Figure 1 shows a schematic layout of the system.

The three hot water storage tanks $(750 \mathrm{~L}$ each) were installed on the ground floor. The tanks were designed to maintain temperature stratification. Tank A was the coldest and connected to the fresh cold-water line (PUB- Public Utility Board). Tank $\mathrm{C}$ was the hottest tank and supplied hot water to the shower cubicles. The stratification was maintained by three solenoid valves installed in the return line to the tanks. These valves were controlled by the data logging system by comparing the temperature of returning solar hot water with the tank temperatures. When there was hot water withdrawal from Tank C (for hot water consumption in showers) an equivalent amount was filled in Tank A. So, the hot water consumption was measured by a flow meter placed in the cold-water line connected to Tank A. To pump the water from the tanks to the panels (in the roof) a centrifugal type circulation pump was used.

The PVT panels were installed on the roof as shown in Fig. 2. The panels were inclined at an angle of $5^{\circ}$, which is close to the $1^{\circ}$ latitude of Singapore, in order to receive maximum solar irradiation and to self-clear the dust from the top glass surface. Three different types of Clusters were installed for comparative study.

The characteristics of the different Clusters are listed in Table 1. The Cluster 1 and Cluster 2 panels were commercially purchased. The Cluster 3 type panels were fabricated in locally in the Solar Energy Research Institute of Singapore (SERIS). Cluster 1 favored electricity generation due to the lack of extra glazing on the panel. This allows more electricity to be harnessed due to less reflection loss from the surface and potentially cooler solar cells. Cluster 2 and Cluster 3 (SERIS) favor thermal energy generation as they have an additional layer of glazing on the panels which reduces thermal losses but could potentially lead to higher solar cell temperatures and lower PV efficiency. Each Cluster was connected to a dedicated inverter (Sunny boy, SMA brand), sized according to the electrical output of the Cluster.

\section{System instrumentation and operational controls}

The system was fully instrumented with necessary sensors. A pyranometer (CMP-11 from Kipp and Zonen) was used to measure the solar radiation, the anemometer was used to measure wind speed, and a Resistance Temperature Detector (RTD) was used to measure ambient temperature. Three electromagnetic flow meters were installed in the three inlet lines of each Cluster to measure the individual total flow rate for each Cluster. Class A type RTDs were used to measure the inlet and outlet temperatures of each Cluster. The tank temperatures, the freshwater inlet temperature, the return water temperature of all Clusters were also measured using individual RTDs. A separate RTD was mounted in the header of one of the collectors of Cluster 1 to sense the temperature of the stagnant water in the collector and to send information to the control system (which would then decide, if it is required to switch on the circulation pump). As described earlier a separate flow meter was installed in the freshwater inlet line (near Tank A) to 




Fig. 1 Schematic layout of water flow loop between storage tanks and PVT modules

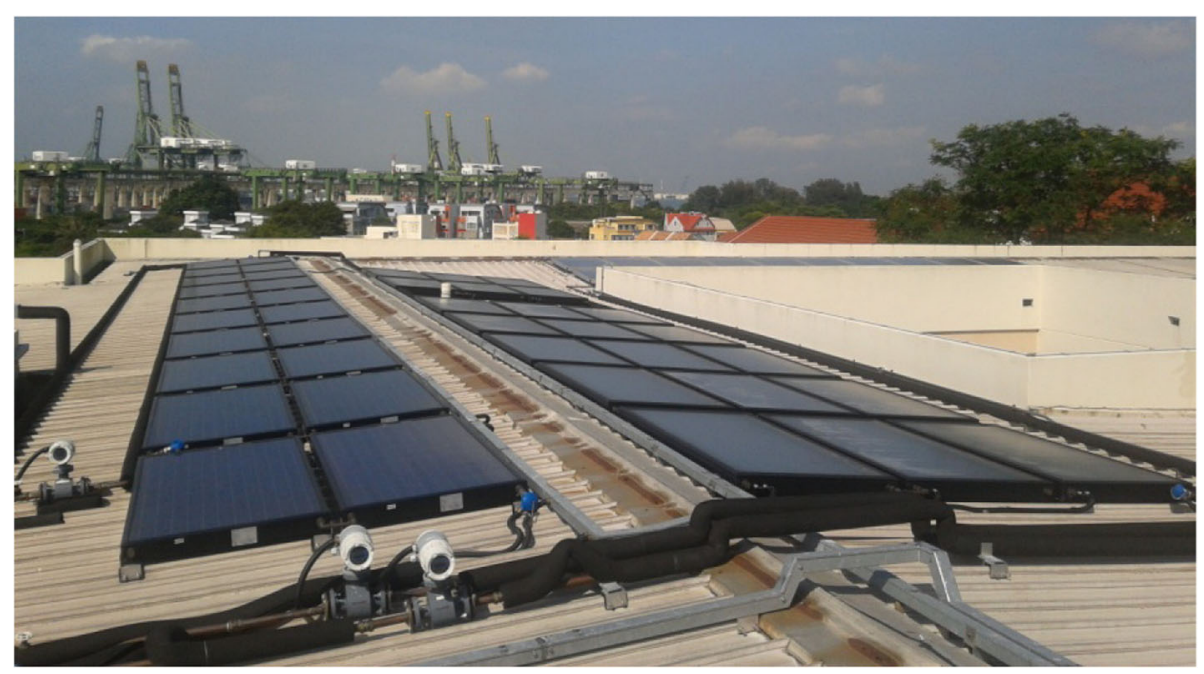

Fig. 2 Photograph of installed PVT modules in the hostel roof 
Table 1 Thermal and electrical characteristics of the 3 different Clusters

\begin{tabular}{|c|c|c|c|c|c|c|c|c|c|}
\hline Cluster No. & $\begin{array}{l}\text { No. of } \\
\text { modules }\end{array}$ & Type & $\begin{array}{l}\text { Thermal } \\
\text { area }\left(\mathrm{m}^{2}\right)\end{array}$ & $\begin{array}{l}\text { Series } \times \text { Parallel } \\
\text { (thermal) }\end{array}$ & $\begin{array}{l}\text { PV } \\
\text { cell }\end{array}$ & PV area $\left(m^{2}\right)$ & $\begin{array}{l}\text { Series } \times \\
\text { Parallel } \\
\text { (electrical) }\end{array}$ & $\begin{array}{l}\text { STC } \\
\text { efficiency } \\
(\%)\end{array}$ & $\begin{array}{l}\text { Electrical } \\
\text { power (kWp) }\end{array}$ \\
\hline 1 & 20 & Unglazed & 26.40 & $2 \times 10$ & Mono & 26.4 & $10 \times 2$ & 14.5 & 3.8 \\
\hline 2 & 21 & $\begin{array}{l}\text { Glazed } \\
\text { PVT }\end{array}$ & 29.60 & $3 \times 7$ & Mono & 28.2 & $10 \times 2$ & 12.3 & 3.5 \\
\hline 3 & 20 & $\begin{array}{l}\text { Glazed } \\
\text { PVT }\end{array}$ & 22.70 & $1 \times 20$ & Multi & 20.0 & $20 \times 1$ & 12.3 & 2.5 \\
\hline
\end{tabular}

measure both the flow rate and accumulated volumetric value. The inverters metered the amount of electricity fed into the grid. There were energy meters installed in each of the floor levels to measure the amount of auxiliary electrical energy consumed for showering.

A customized program designed in Lab View was written to configure data acquisition, store data into files, display the captured data in a live manner visually and finally to control the circulation pumps and solenoid valves in the tanks. The data collection rate was set to $120 \mathrm{~s}$. The program also compares the temperature of the stagnant water in one of the collectors of Cluster one and compares it with Tank A temperature and if it is more than a user-defined setting (typically $4-5^{\circ} \mathrm{C}$ ) the circulation pump is switched on. When the return water temperature does not get heated up sufficiently above the lowest tank temperature (typically if the difference is less than $1{ }^{\circ} \mathrm{C}$ ) the circulation pump is switched off. The data acquisition program also compares the return water temperature with the three tank temperatures to open the correct solenoid valve to maintain temperature stratification. The program stored all the data in a daily $\log$ file and displays the data graphically in a live manner. The display was set up in a student lounge room to increase the awareness of non-renewable energy options to students.

To make the system more effective, a separate temperature controller cum relay system was installed to prevent electricity supply to electric water heaters in shower cubicles when the storage tank (tank C) temperature is above $40^{\circ} \mathrm{C}$.

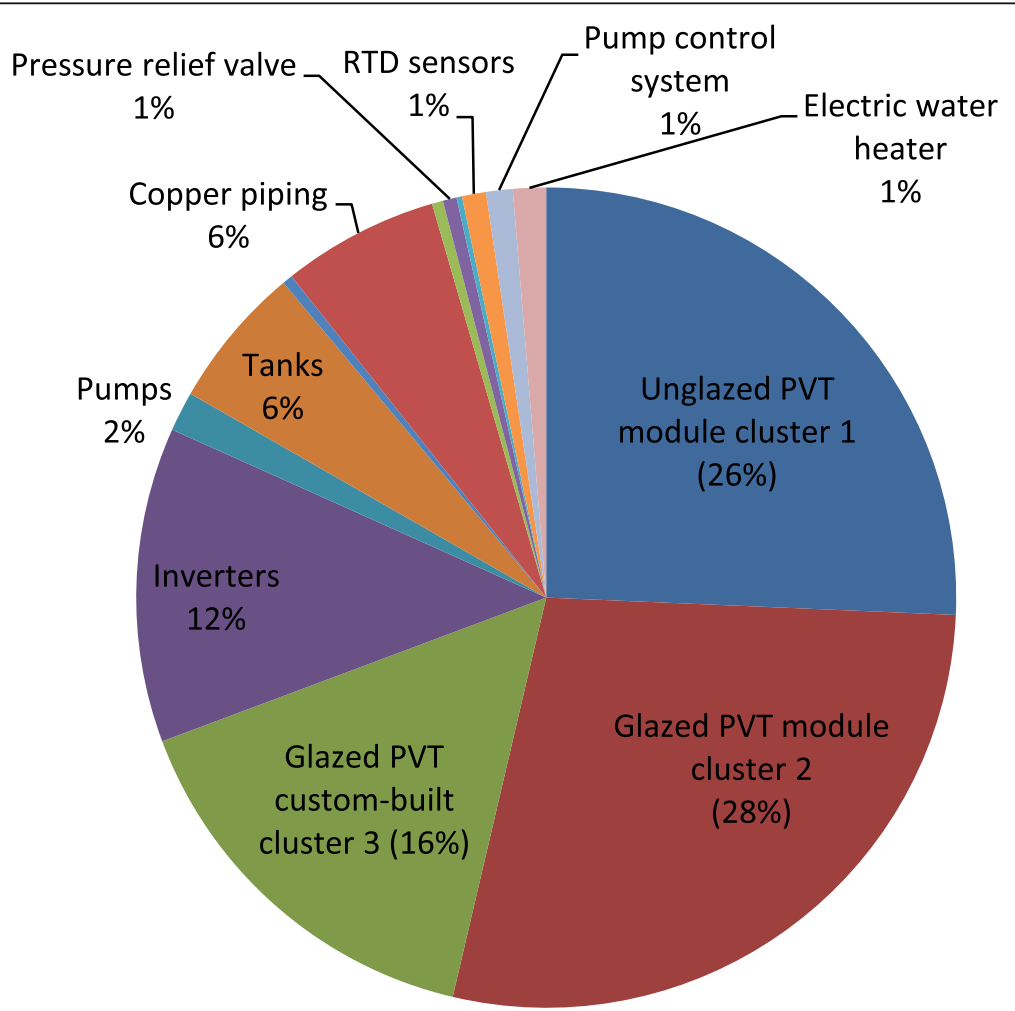

Fig. 3 Distribution of material costs in a typical PVT system 




Fig. 4 Distribution of various installation costs involved in a typical PVT system

\section{Economic analysis}

The high initial cost is a bottleneck to widespread commercial use. It is therefore required to do an economic analysis, which is usually specific to the technology of the solar panels, solar radiation and climate at the installation site, load pattern profile, bank interest rates and the cost of conventional sources of energy. For the present economic analysis, we will base it on the yearly performance, but excluding vacation periods (assuming that hostel occupancy rate can be maintained always). The cost and benefits are indicated in local currency Singapore dollars (SGD). As per the exchange rate as on November 2019, 1 USD is equal to 1.36 SGD. As in any economic analysis, the initial investment or the cost is calculated and compared with the yearly benefits or returns.

The total cost of a solar PVT system involves material costs and installation costs. For a typical system as described above, it is estimated that the material costs are about 46,000 SGD and installation costs are about 14,000 SGD. (It is to be noted that the extraneous costs incurred due to the installation of various sensors, meters, data acquisition system, computer control software, etc., which are part of a research system are not included

Table 2 Economical value of annual benefits of PVT system

\begin{tabular}{lll}
\hline Item & Output & Benefits \\
\hline Electrical energy & $10,235 \mathrm{kWh}$ & $\$ 2696$ \\
Solar thermal energy & $16,511 \mathrm{kWh}$ & $\$ 4578$ \\
\hline
\end{tabular}

in the cost of a typical commercial system as they are not required for a normal commercial system). The various components of materials and installation costs are depicted below in Figs. 3 and 4.

The total cost of the system includes capital investment, annual operation and maintenance (O\&M) costs, and the electricity costs - for pumps and for auxiliary heating (during low radiation days). For the current case the capital investment was 59,988 SGD and annual O\&M cost was 600 SGD. The annual power consumption for auxiliary heating was $1301 \mathrm{kWh}$.

The benefits of the system are the electricity generated and the electricity equivalent that is saved using solar hot water for showers. If the hostel can be maintained at full occupancy throughout the year the corresponding

Table 3 Typical values of different parameters used in economic analysis

\begin{tabular}{ll}
\hline Parameter & Value \\
\hline Annual O\&M cost & $1 \%$ of total investment cost \\
Decommissioning cost & $5 \%$ of total investment cost \\
Salvage cost & $5 \%$ of total investment cost \\
Lifetime of system & $25 \mathrm{yr}$ \\
Discount rate & $5 \%$ \\
Inflation rate & $2.4 \% \mathrm{yr}^{-1}$ \\
Degradation rate [11-13] & $0.75 \% \mathrm{yr}^{-1}$ \\
Electrical tariff [14] & SGD $0.2634 \mathrm{kWh}^{-1}$ \\
\hline
\end{tabular}






Fig. 5 Typical variation of water temperatures at Cluster exits and tank temperatures during a typical sunny day

annual electrical and thermal output are listed in Table 2 along with the equivalent monetary value (based on the current electricity tariff of 26 cents $\mathrm{kWh}^{-1}$ ).

For the subsequent economic analysis being carried out the typical values listed in Table 3 has been used. The annual degradation rate was fixed as $0.75 \%$ based on previous reports [11-13]. Discount rate of $5 \%$ was based on the prevailing bank loan interest rates in Singapore. The electricity prices were taken from Energy market authority of Singapore's website [14]. The operation and maintenance costs, decommissioning cost and salvage value were estimated based on discussion with PV installation contractors.

Net present value (NPV) is calculated based on the Eq. (1).

$$
\mathrm{NPV}=-\mathrm{C}_{0}+\sum_{\mathrm{i}=1}^{\mathrm{t}} \frac{\mathrm{C}_{\mathrm{i}}}{(1+\mathrm{r})^{\mathrm{i}}}
$$

where $\mathrm{C}_{0}$ is the initial investment

$\mathrm{C}$ is the Cash Flow (due to benifits)

$r$ is the discount rate

$\mathrm{t}$ is the total system life time.

\section{Results and discussion}

Typical daily performance of the system

A typical thermal performance of the whole system is shown in Fig. 5. The solar radiation on a typical clear day has a parabolic variation as shown. The daylight hours are from $7 \mathrm{am}$ to $7 \mathrm{pm}$. When the solar radiation rises to a sufficient value, the pump circulation starts and the Cluster outlet temperatures $\mathrm{T} 4, \mathrm{~T} 5$ and $\mathrm{T} 6$ begin to rise. The tank temperatures also rise during the day and the stratification is minimal during pump circulation. The maximum



Fig. 6 Typical variation of thermal efficiency of Cluster 2 during a sunny day 


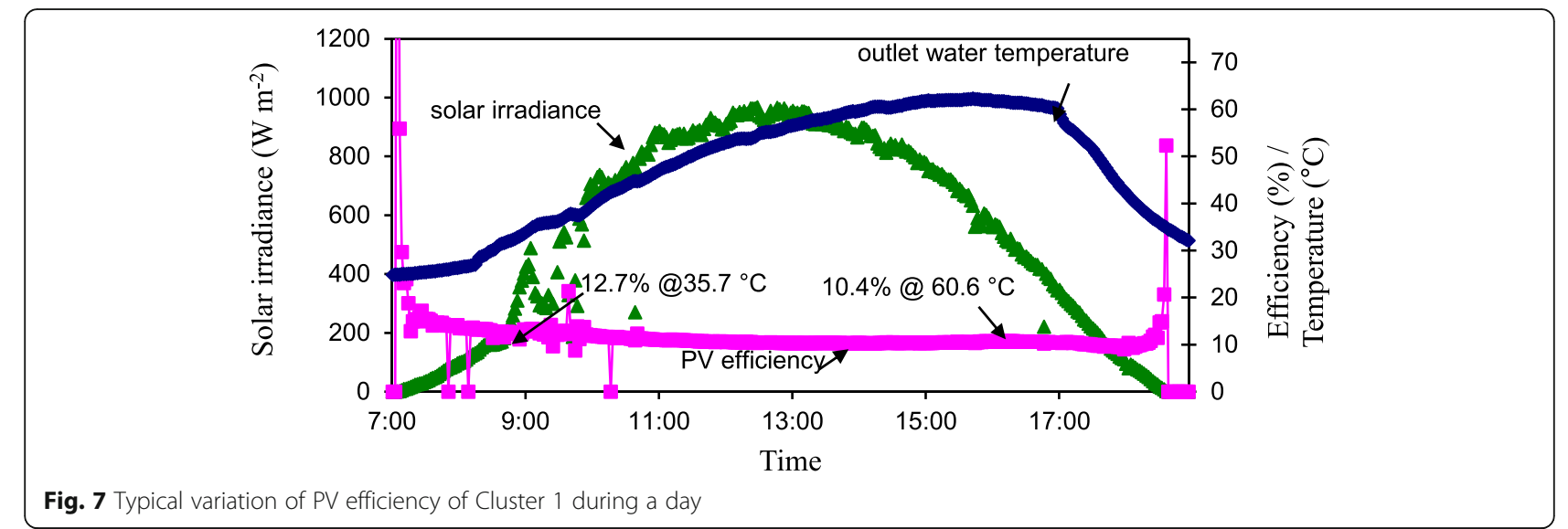

tank temperature during the day is typically about $65^{\circ} \mathrm{C}$. However, during the night when there is more hot water consumption, the addition of fresh water to tank A reduces the temperature of tank A drastically.

A typical performance of the thermally dominant glazed (Cluster 2) PVT panel is depicted in Fig. 6. Thermal efficiency is the ratio of thermal energy collected in the form of hot water to the total solar energy falling on the thermal collector area. A detailed expression is provided later in Eq. (3). It is seen that the thermal efficiency is about $30 \%$ in the morning period but degrades to about $15 \%$ in the late evening due to high inlet water temperature. This can be averted if the produced hot water is utilized during the day itself or if we have alternate batch of thermal tanks.

PV efficiency is the ratio of electrical energy produced by the PV panels to the total solar radiation received over the PV collector area. A more detailed expression is provided in Eq. (4). The variation of PV efficiency over the day with varying radiation and water outlet temperature is depicted in Fig. 7 for Cluster 1 (unglazed panels). It is observed that the PV efficiency is strongly affected by water temperature flowing below the panel. It was observed that during the end of the day when the water temperature becomes high, the efficiency drops to $10.4 \%$ at $60.6{ }^{\circ} \mathrm{C}$. This brings out an important requirement for implementation of PVT systems, which is the need to have a continuous thermal load during the day to prevent overheating of water in the thermal storage tanks. In the present scenario, the thermal load was concentrated only in the evenings and early mornings when most of the showers were taken. Usually the electricity contributed by the PV panels offsets only a small portion of the whole building which has other needs than hot water like fan, lighting, computers etc. Therefore, all the electricity produced by PVT system is consumed by the building. Even in rare cases when the electrical capacity of PVT

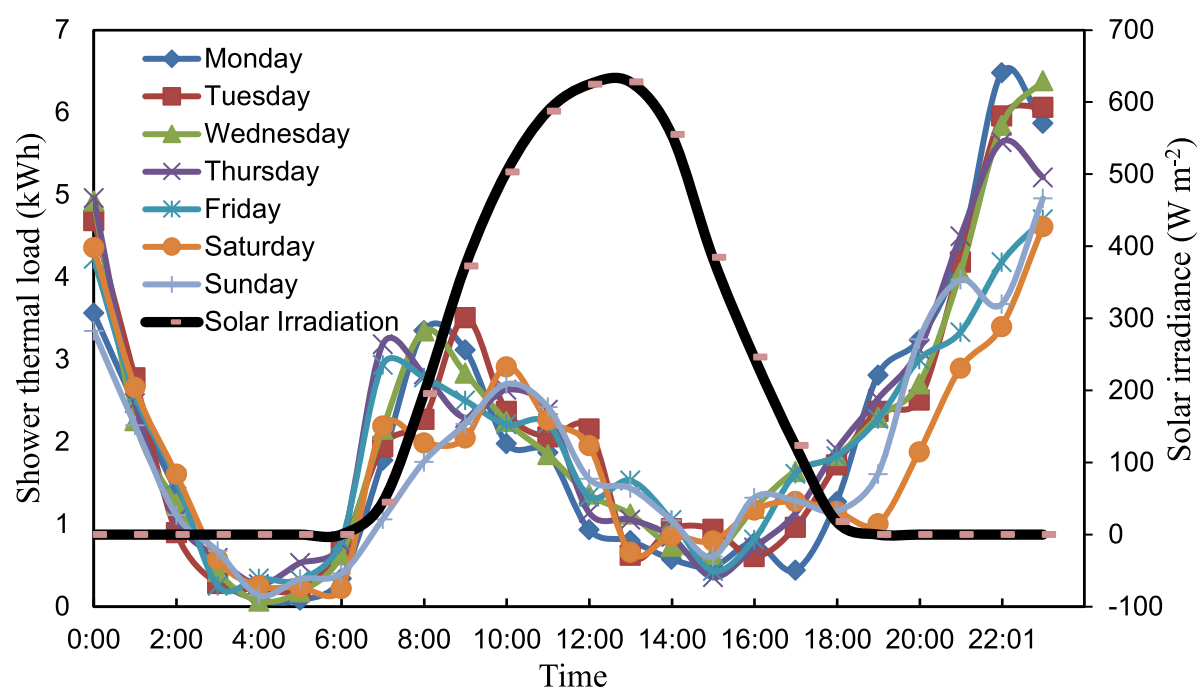

Fig. 8 Typical variation of thermal load (hot water shower) during a day 
Table 4 Yearly electrical and thermal output of the system and auxiliary energy consumption

\begin{tabular}{llllll}
\hline Months & Average solar irradiance & Average thermal output & Average electrical output & Average auxiliary energy & Average hot water consumption \\
\hline & $\left(\mathrm{kWh} \mathrm{m}^{-2}\right)$ & $\left(\mathrm{kWh} \mathrm{d}^{-1}\right)$ & $\left(\mathrm{kWh} \mathrm{d}^{-1}\right)$ & $\left(\mathrm{kWh} \mathrm{d}^{-1}\right)$ & $\left(\mathrm{m}^{3}\right)$ \\
Sep & 4.8 & 67.5 & 31.9 & 0.2 & 1.39 \\
Oct & 4.4 & 64.1 & 29.9 & 1.2 & 1.76 \\
Nov & 3.8 & 60.1 & 25.8 & 3.3 & 2.80 \\
Dec & 3.1 & 43.4 & 21.4 & 0.8 & 0.79 \\
Jan & 4.6 & 58.8 & 27.5 & 1.8 & 1.79 \\
Feb & 3.5 & 53.2 & 23.7 & 3.9 & 0.90 \\
Mar & 4.2 & 64.4 & 30.1 & 0.0 & 1.09 \\
Apr & 4.8 & 55.1 & 24.9 & 0.8 & 2.26 \\
May & 6.5 & 47.1 & 25.6 & 0.0 & 0.73 \\
Jun & 4.7 & 40.8 & 26.8 & 0.0 & 0.27 \\
Jul & 4.1 & 40.7 & 23.7 & 0.9 & 0.79 \\
Aug & 4.5 & 56.1 & 29.1 & 0.0 & 1.63
\end{tabular}

system is comparable to the building electricity demand, there are options to store the electricity in batteries or to sell the electricity to the grid. So, it is ideal to operate the PVTs with maximum PV efficiency to gain the maximum amount of electricity. Consequently, if the end application has a continuous thermal load demand, the inlet water temperature fed into the PVT system will be lower and will lead to higher thermal and electrical efficiencies of the system.

Figure 8 shows the typical daily thermal load pattern over a week based on energy requirement for hot water showers on an hourly basis. It reflects very minimal load in the afternoons when the solar radiation is at its maximum. To alleviate this problem either a hot water load can be created during the day (like washing clothes and vessels etc.) or can have a set of backup thermal storage tanks which can act as energy storage when the main tanks have reached a high-temperature value.

The system required minimal maintenance and the hostel could use the system without additional manpower or training for the staff. The hostel improved its score on points awarded for green building initiatives and did win an award as the best green hostel in a competition amongst various hostels in the university. The students were not disturbed by the new system and continued to use hot water for showers as normal. The main obstacle or bottle neck was to educate the students to choose the solar hot water line first instead of the existing conventional electric heater. But despite extensive orientation and posters in individual shower cubicles, finally to improve hot water utilisation, a relay system to switch off the power supply to electric water heaters when the temperature of the supply tank was above $40^{\circ} \mathrm{C}$ as described in section 2.2, had to be installed.

\section{Yearly performance}

Table 4 shows the yearly performance of the installed system during the period September to August. The daily average of solar radiation was $4.39 \mathrm{kWh} \mathrm{m}^{-2}$ and the average thermal and electrical energy output were 54.3 and $26.7 \mathrm{kWh}$. The daily average hot water consumption was $1.5 \mathrm{~m}^{3}$ and auxiliary energy consumption $\left(\mathrm{E}_{\text {aux }}\right)$ was in the range of 1 to $3.5 \mathrm{kWh}$. The months of December, May, June and July have lower hot water consumption due to vacation periods resulting in lower occupancy rates in the hostel. This is also reflected in the lower thermal output. This again emphasizes the fact that there is a need to have a good thermal demand to operate a PVT system at its maximum efficiency, both thermally and electrically.

\section{Thermal efficiency of the three different clusters}

The thermal output from each cluster is calculated using Eq. (2) below

$$
\begin{aligned}
& \text { Thermal Output }= \text { ( } \\
& \times(\text { specific heat capacity of water }) \\
& \times(\text { change in temperature of flowing } \\
& \text { water between inlet and exit } \\
&\text { headers of each cluster }) \\
& \times(\Delta t, \text { data acquisition time interval })
\end{aligned}
$$

Hence, the thermal efficiency of the different clusters is given in Eq. (3) below:

$$
\eta \text { th }=\frac{\text { Total Thermal output for a day }}{(\text { Daily Solar irradiation during pump ON time }) \times(\text { Collector area })}
$$

The average annual thermal efficiencies ( $\eta$ th) were 8,25 and $26 \%$ for cluster 1,2 and 3 respectively. Cluster 1 being unglazed without additional glass 


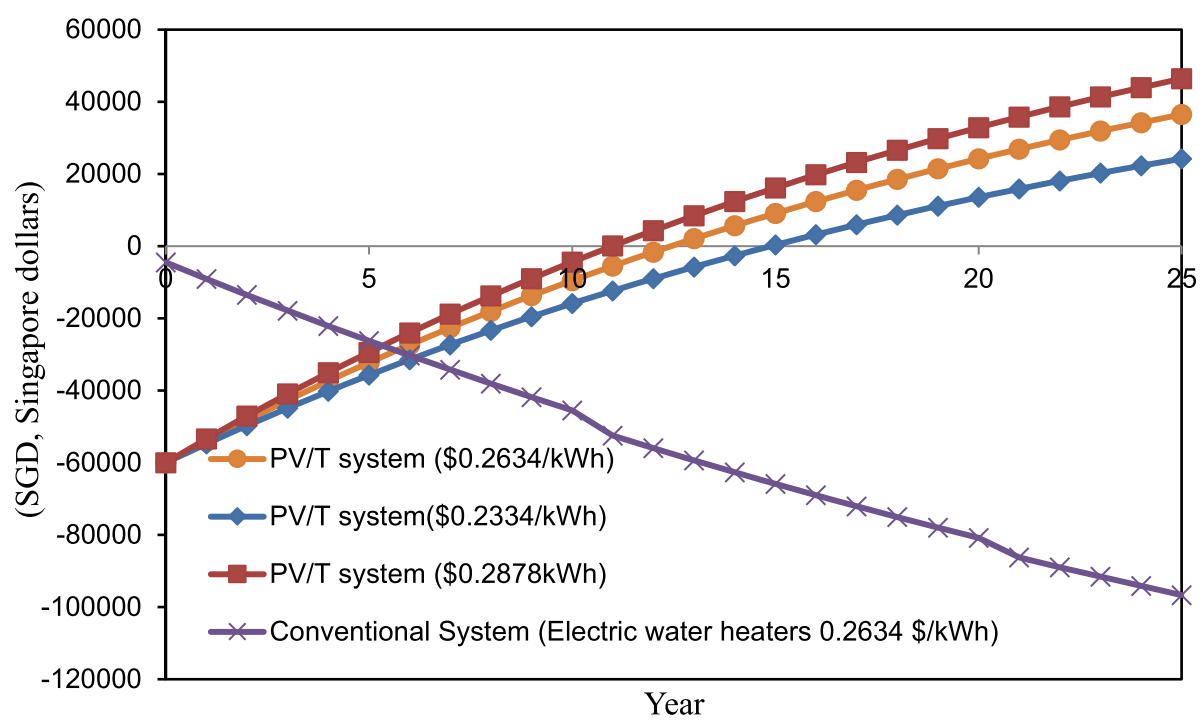

Fig. 9 Cumulative cash flow variation of a PVT system and a conventional water heater system with time for various electricity prices

layer with air gap has higher heat loss to ambient and therefore has lower thermal efficiency. For clusters 2 and 3 which have an additional glazing layer on the top of the module with an air gap, the heat loss is minimized, and the trapped heat enables the modules to have higher thermal efficiencies. But the challenge in this type of glazed modules is to have a very good watertight seal for the air gap to prevent atmospheric moisture/rainwater getting trapped inside the air gap. Such a phenomenon does reduce the PV efficiency drastically. In the current test bedding cluster 2 faced considerable moisture/water trapping in the air gap which subsided after few days of sunshine. Cluster 3 was also affected but with less intensity.

\section{Electrical efficiency of the three different clusters}

Electrical efficiency (nel) was defined as in Eq. (4) below

$$
\eta \mathrm{el}=\frac{\text { Total electrical output for a day }}{(\text { Daily Solar irradiation }) \times(\text { Collector area })}
$$

Since each cluster of panels were connected to individual inverters it was possible to track the individual performance of the clusters. The annual average of daily electrical efficiencies was 11.7, 7.4 and 8.2\% for clusters 1,2 and 3 respectively compared to their STC (Standard Test Conditions) efficiencies of 14.5, 12.3 and $12.3 \%$. One of the main reasons for the significant drop in efficiency for cluster 2 and 3 is the higher operating temperature of the module due to high temperature water flowing beneath the module and having low heat loss due to additional glazing layer. However, this effect can be minimized if there was sufficient utilization of hot water which would have helped in maintaining the tank water temperature to lower values and would increase both thermal and electrical efficiencies.

\section{Economic analysis}

Economic analysis was carried out as described in section 2.2 and the results are presented below. The net present value (based on all returns until $25 \mathrm{yr}$ of system lifetime) is calculated to be $\$ 36,430$. Figure 9 depicts the cash flow of the system during the course of system's lifetime and compares with that of a conventional system using electrically powered water shower heaters (which is assumed to have a lifetime of $10 \mathrm{yr}$ ).

It can be seen from Fig. 9 that the payback period (when cumulative cash flow becomes zero) is $12.5 \mathrm{yr}$ for the current electricity price of 26 cents $\mathrm{kWh}^{-1}$ and changes to 11 and $15 \mathrm{yr}$ when the electricity price is 28 and 23 cents respectively. So, the PVT system is more attractive in places where the grid electricity is of higher cost, though it does provide enough positive impetus even in the current price of 26 cents $\mathrm{kWh}^{-1}$.

Also, for the conventional system, though it starts off with a small capital investment, the operating costs are high with no benefits or savings and thus the net present value keeps decreasing continuously. The internal rate of return (defined as the discount rate at which cumulative cash flow becomes zero for the period during which the system is in good operating condition) is calculated to be $10.2 \%$ for PVT system (for electricity cost of 26 cents $\mathrm{kWh}^{-1}$ ). However, if a four-month vacation period is taken into account, during which hot water utilization will lower down to $25 \%$ of normal use, the internal rate of return is $4.9 \%$ and payback period is about $22 \mathrm{yr}$. Alternatively, the whole system can be designed to meet 
only the baseload (25\% in this case) which will make it economically more favourable and the payback period of $7-8$ yr can be achieved.

It should be noted that this installation, being a oneof-a-kind or first in Singapore, the total cost is relatively high, however, when it is reduced to practice and is installed by an established process flow, the overall price of the system is expected to be significantly lower. With more projects being installed the design, engineering and approval costs can be brought down and with applications involving higher hot water utilization the returns will be more attractive.

\section{Conclusions}

The present work demonstrated the feasibility of installing a PVT system in a tropical climate. The present study has established the typical showering thermal load pattern in student hostels which can be used by future researchers for simulation studies. It is clear that the performance of a PVT system is strongly influenced by the load profile and it is essential to make arrangements to consume the thermal energy immediately after it is produced, to be able to run the system efficiently. Glazed PVT modules have higher thermal efficiencies compared to unglazed PVT modules. It may be better to have separate flow loops and tanks for unglazed PVT collectors to maximize energy recovery. The typical cost of a PVT system is determined and the calculated payback period (for a full year utilization scenario) of $12.5 \mathrm{yr}$ and can further be improved with higher hot water utilization. With more and more shortage of roof space, PVT technologies will be an attractive option, particularly in applications where there is a large thermal load during the day and also at places where the grid electricity prices are high.

\section{Acknowledgements}

We are thankful to the Solar Energy Research Institute of Singapore (SERIS) for hosting this project. We also acknowledge the hostel authorities of Temasek Hall, National university of Singapore for their permission to allow the testing of a PVT system in one of their blocks in their hostel.

\section{Authors' contributions}

Prof AT was the lead PI of the project and planned and supervised the project execution. Dr. SS joined the project as a post doc and executed the project implementation, data collection, data analysis and manuscript preparation. Both authors read and approved the final manuscript.

\section{Authors' information}

Prof Andrew Tay has retired from National university of Singapore and is an adjunct researcher in Singapore University of technology and Design. Dr. Sivanand Somasundaram is currently Senior research scientist at Experimental Power Grid centre, ERI@N, NTU, Singapore.

\section{Funding}

This work was supported by EDB (Economic development board) of Singapore under the project NRF2008EWT-CERP002-027.

\section{Availability of data and materials}

All data generated or analysed used for this publication is already presented in the form of graphs and tables. There are no other specific data files to be deposited.

\section{Competing interests \\ The authors declare they have no competing interests.}

Received: 6 May 2019 Accepted: 15 November 2019

Published online: 12 December 2019

\section{References}

1. Besheer AH, Smyth M, Zacharopoulos A, Mondol J, Pugsley A. Review on recent approaches for hybrid PV/T solar technology. Int J Energ Res. 2016; 40:2038-53

2. Reddy SR, Ebadian MA, Lin CX. A review of PV-T systems: thermal management and efficiency with single phase cooling. Int J Heat Mass Tran. 2015;91:861-71.

3. Michael JJ, Iniyan S, Goic R. Flat plate solar photovoltaic-thermal (PV/T) systems: a reference guide. Renew Sust Energ Rev. 2015;51:62-88.

4. Kumar P, Singh AK, Sudhakar K, Gupta V. Cooling techniques on the flat plate soalr photovoltaic-thermal systems: an overview. Int J Eng Sci Res. 2016;6:184-91

5. Farshchimonfared M, Bilbao Jl, Sproul AB. Full optimisation and sensitivity analysis of a photovoltaic-thermal (PV/T) air system linked to a typical residential building. Sol Energy. 2016;136:15-22.

6. Guo JY, Lin SM, Bilbao JI, White SD, Sproul AB. A review of photovoltaic thermal (PV/T) heat utilisation with low temperature desiccant cooling and dehumidification. Renew Sust Energ Rev. 2017;67:1-14.

7. Dubey S, Tiwari GN. Life cycle cost analysis and carbon credit earned by hybrid PV/T solar water heater for Delhi climatic conditions. Open Environ J. 2008;2:15-25.

8. Good C. Environmental impact assessments of hybrid photovoltaic-thermal (PV/T) systems - a review. Renew Sust Energ Rev. 2016;55:234-9.

9. Shihabudheen $M$, Arun P. Performance evaluation of a hybrid photovoltaicthermal water heating system. Int J Green Energy. 2014;11:969-86.

10. Dubey S, Tay AAO. The theoretical modelling and optimization of a $10 \mathrm{~kW}$ photovoltaic thermal system for a student hostel in Singapore. Int J Green Energy. 2014;11:225-39.

11. Carvalho MJ, Páscoa S, Mexa N, Gonçalves R, Correia J, Gano A, et al. Solar thermal collector's degradation - influence of corrosivity inside and outside the collectors. In: ISES Solar World Congress 2017 and IEA SHC International Conference on Solar Heating and Cooling for Buildings and Industry. Abu Dhabi; 2017.

12. Fan J, Chen Z, Furbo S, Perers B, Karlsson B. Efficiency and lifetime of solar collectors for solar heating plants. In: ISES Solar World Congress 2009 Johannesburg; 2009. p. 11-4.

13. Jordan DC, Kurtz SR. Photovoltaic degradation rates - an analytical review. Prog Photovoltaics. 2013;21:12-29.

14. EMA. Electricity tariffs. Singapore: Energy Market Authority; 2019.

\section{Publisher's Note}

Springer Nature remains neutral with regard to jurisdictional claims in published maps and institutional affiliations.
Ready to submit your research? Choose BMC and benefit from:
- fast, convenient online submission
- thorough peer review by experienced researchers in your field
- rapid publication on acceptance
- support for research data, including large and complex data types
- gold Open Access which fosters wider collaboration and increased citations
- maximum visibility for your research: over $100 \mathrm{M}$ website views per year
At BMC, research is always in progress.
Learn more biomedcentral.com/submissions 